\title{
Etnografía del municipio de Santa María Ostuma; tierra de la piña, leyendas y tradiciones
}

DOI: http://dx.doi.org/10.5377/koot.v0i10.6703

URI: http://hdl.handle.net/11298/789

\author{
Lic. Carlos Osegueda \\ Antropólogo y docente investigador \\ Universidad Tecnológica de El Salvador \\ carlos.osegueda@utec.edu.sv
}

\section{Resumen}

Se exponen los resultados de la investigación realizada en el año 2017, impulsada por un docente y sus estudiantes, de la carrera de la licenciatura de antropología -Utec, desde un enfoque de la antropología sociocultural, dimensionan las expresiones socio-históricas y organizativas-culturales del municipio, que surgen a partir de la producción y comercialización del producto insignia; "La piña".

Se explican las dinámicas locales como el emprendimiento económico, la proyección y construcción patrimonial tangible e intangible entorno a la fruta, que se ve manifiesta en las creencias, la producción artística, las leyendas y tradiciones religiosas-espirituales, ejemplo de ello las palancas, las ferias de la piña y la mayordomía a la santa patrona la virgen de Candelaria, entre otras. El método aplicado fue cualitativo-etnográfico, desarrollando entrevistas, grupos focales, aplicando software para análisis cualitativo Nvivo, además se utilizó el drone, permitiendo un registro de lugares emblemáticos del municipio. Entre los resultados se menciona la piña como el producto por excelencia en el municipio; destacando la variedad de azucarón o india, que como se verá más adelante, es el fruto tradicional, a la que le llaman "el patrimonio Ostumeño"; confiriendo un sentido de arraigo o pertenencia a los habitantes de la villa ostumeña.

Palabras claves: Patrimonio cultural; Antropología; Etnografía; Cultura; Identidad cultural. 


\begin{abstract}
The students and the faculty of the school of Anthropoloy at UTEC conducted an ethnographic work on the municipality of Santa María Ostuma in 2017 which results have been presented in an article. The study included an approach based on sociocultural anthropology, providing the dimension of the socio-historical and cultural-organizational expressions of this municipality, based on the production and commercialization of their emblematic product: the pineapple.

Different local dynamics are explained within this study, such as the economic entrepeneurship of the people and the tangible and intangible patrimonial construct around this fruit, which can be seen in the beliefs, artistic production, legends and the spiritual-religious traditions. An example of these are the palancas--logs with hanging pineapples, coconuts, oranges, moonshine and animals that are carried during the procession--, the pineapple fairs and the mayordomía--select group of people in charge of the festivities-- to the patron saint Virgin of Candelaria, among others.

The study applied an ethnographic-qualitative method thus interviews and focal groups were used; data was analyzed with Nvivo. A drone also videotaped the emblematic places of the municipality. Among the results it can be mentioned that the pineapple is viewed as the most relevant product of the area, being in first place the azucarón (extra sweet) or india (creole) varieties. The pineapple is seen as the traditional fruit that they call "the heritage of Ostuma" hence conferring onto it a sense of belonging for the inhabitants of the municipality.
\end{abstract}

Keywords: Cultural heritage; Anthropology; Ethnography; Culture; Cultural identity.

\title{
Introducción
}

En El Salvador existe un crisol de manifestaciones culturales, que pueden ser ancestrales o contemporáneas, lo que le permite ofrecer a propios y extraños su riqueza, en este sentido, a lo largo y ancho de su territorio. En ese marco de las identidades locales emerge el municipio de Santa María Ostuma, que está situado en el departamento de La Paz y pertenece a la reconocida región de los pueblos nonualcos.

Según Larde y Larín (2000), Ostuma, en idioma náhuat, significa "Las cinco barrancas" o "Las cinco cuevas", pues proviene de ostu, ostuc, ustuc ("cueva", "barranca") y ma ("mano"), o bien, ma, radical de maquil ("cinco"), estas dos últimas son sinónimas, pues como la numeración era quinario-vigesimal, o sea 
que contaban por cincos y por veintes; resulta que "una mano de mazorcas de maíz" equivale a cinco mazorcas.

En la actualidad se cuenta con muy pocas referencias socio-históricas y culturales del municipio, de las cuales se pueden mencionar el acercamiento teórico desde la Corporación de Municipalidades de la República de El Salvador (Comures) y las notas periodísticas con respecto a la actividad turística, que se ha vuelto a través del tiempo la marca municipal, el "Festival de la piña", dándole el nombre hasta ser reconocida como "Santa María Ostuma: la capital de la piña". Por lo anterior, se vuelve importante el impulso de una investigación cualitativa con enfoque etnográfico, realizada por profesionales de la Antropología, que sustente, de manera sistemática, el aporte que hace desde su patrimonio natural y cultural Santa María Ostuma, así como registrar las diferentes variedades gastronómicas que comercializan sus habitantes mediante su producto emblemático: la piña. Es importante contextualizar tanto su producción agrícola en el desarrollo de su economía, así como la tradición oral y escrita, que hace referencia al legado ancestral pipil y a su memoria histórica reciente reflejados en las leyendas y tradiciones, tales como las palancas, las entradas, las cofradías, las mayordomías y las romerías, en su fiesta patronal en honor a la Virgen de Candelaria, entre otros; que denotan la particularidad de los ostumeños en la región nonualca y cómo ello aporta a las identidades nacionales.

Es así que la investigación se propuso los siguientes objetivos:

\section{Objetivo general}

Identificar las manifestaciones socioculturales, tangibles e intangibles, del municipio de Santa María Ostuma, en el departamento de La Paz.

\section{Objetivos específicos}

- Describir la historia del municipio de Santa María Ostuma.

- Describir procesos de emprendimiento en torno al fruto de la piña, el papel de la mujer en dichos procesos productivos, así como el cambio sociocultural generado en el municipio en relación con esta.

- Identificar los polos de desarrollo económico que distinguen a Santa María Ostuma de los demás municipios de la región nonualca.

- Recabar las manifestaciones de patrimonio cultural tangible e intangible del municipio de Santa María Ostuma.

- Describir la composición de los grupos domésticos locales, de los cantones aledaños al casco municipal, así como las estructuras de participación social y comunitaria. 


\section{Marco teórico- conceptual}

\section{Cotidianidad municipal abordada desde la Antropología cultural}

La Antropología cultural es una disciplina que destaca los aspectos no biológicos del hombre y su sociedad; explica los componentes sociales, lingüísticos y tecnológicos que están detrás de las conductas humanas (Hope Ponce \& Mora Eguiarte, 2000).

Asimismo, Miller (2016) argumenta lo siguiente:

La antropología cultural es el estudio de los pueblos contemporáneos y sus culturas. El termino cultura se refiere a las creencias y comportamientos aprendidos y compartidos por las personas. La antropología cultural se ocupa de las variaciones y semejanzas que existen entre las culturas, y como la cultura cambia en el tiempo (p. 7).

Por tanto, este campo de aplicación de la Antropología, que enfatiza en el aspecto cultural de los pueblos, permite enfocar los hallazgos del trabajo de campo en el municipio de Santa María Ostuma; da la pauta para profundizar su esencia desde sus tradiciones y costumbres,

\section{Identidad sociocultural del municipio de Santa María Ostuma}

Primero hay que definir el concepto de cultura; y para ello se puede citar uno de los considerados padres de la Antropología, el antropólogo E. B. Tylor (1871), citado en Barfield (2001), quien considera que cultura es "ese todo complejo que incluye el conocimiento, las creencias, el arte, la moral, el derecho, la costumbre y cualesquiera otras capacidades y hábitos adquiridos por el hombre como miembro de la sociedad".

Ayllón (2013) define la cultura como:

Un término que encierra muchos sentidos. Hace referencia a una manera de vivir el mundo e interpretarlo (la cultura occidental); al conjunto de técnicas y recursos que nos ayudan a vivir (tecnología); a las instituciones que organizan nuestra convivencia (democracia, universidad, clubs deportivos); a las ideas y creencias de los pueblos e individuos...esta variedad incluye la denominada "cultura material", constituida por productos materiales fabricados por el hombre, y la que conocemos como "cultura mental", integrada por formas de pensar, creencias, costumbres, valores y normas.

La cultura engloba, por tanto, todo lo que los seres humanos han producido para adaptarse a su entorno físico y social, desde sus recursos técnicos para sobrevivir hasta las leyes que configuran la sociedad (pp. 176-177). 


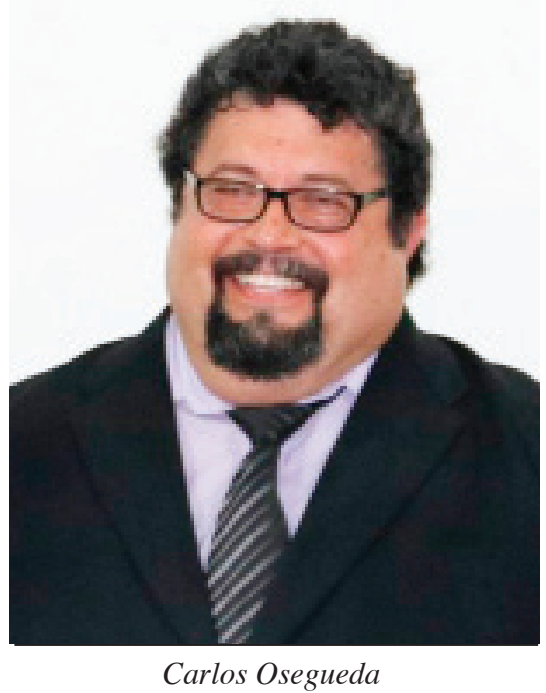

Por su parte, la Unesco (1982), citado en Vásquez (2018), al realizar en México la Conferencia Mundial sobre las Políticas Culturales, en la que la comunidad internacional contribuyó de manera efectiva a definir la cultura destacando ocho trazos con la siguiente declaración:

La cultura es un sistema de creencias, valores, costumbres, La cultura puede considerarse actualmente como el conjunto de los rasgos distintivos, espirituales y materiales, intelectuales y afectivos que caracterizan a una sociedad o un grupo social. Ella engloba, además de las artes y las letras, los modos de vida, los derechos fundamentales al ser humano, los sistemas de valores, las tradiciones y las creencias y que la cultura da al hombre la capacidad de reflexionar sobre sí mismo. Es ella la que hace de nosotros seres específicamente humanos, racionales, críticos y éticamente comprometidos. A través de ella discernimos los valores y efectuamos opciones. A través de ella el hombre se expresa, toma conciencia de sí mismo, se reconoce como un proyecto inacabado, pone en cuestión sus propias realizaciones, busca incansablemente nuevas significaciones, y crea obras que lo trascienden (p. 2).

Ya definido el concepto de cultura, se puede definir identidad sociocultural tal como lo propone Campo A. (2008):

Es aquel aspecto de la conciencia individual de sí mismo, que surge de reconocimiento de la pertenecía de un sujeto a su comunidad o grupo social, y que incluye dimensiones emotivas y axiológicas (valores).

La identidad cultural es un proceso común a todos los seres humano y trascurre en cualquier época de la historia o zona geográfica. Forma parte de 
la conciencia del yo, de la conciencia de pertenecía una colectividad, de la diferencia especifica con otros y está ligada a espacios ideológicos.

La identidad es un laberinto, una complejidad de ámbitos distintos, no es posible establecer una definición cerrada, sino, intentar acercarse a través de diversos aspectos que la convierten en un "collage cultural" (un resultado de la cultura). La identidad está vinculada a la alteridad, pues que el "yo" se manifiestas con la existencia de "otro". A partir de esta toma de conciencia acepta o nos preguntamos ¿quiénes soy yo?, ¿quién es el otro?

Este otro presenta límites de lo que no se es y al mismo tiempo conexiones con aquellos que es similar, porque la diversidad también es un factor preponderante en lo que se refiere a identidad, demostrando los rasgos distintivos culturales y, en ocasiones, idealizados.

La identidad también hace referencia a la historia de un grupo específico, convirtiendo ciertos sucesos de esa sucesión temporal en algo perenne, que agrupa a los miembros de esos pueblos y naciones bajo diversas formas cívicas.

La identidad se define a partir de la presencia del "otro" a partir de encuentro mencionado. Aquella presencia permite tomar conciencia sobre el "yo", y este último construye, a su vez, al otro "Otro", pues lo categoriza, lo identifica o le coloca la etiqueta de extranjeros. En este "juego" calificador la alteridad participa en la construcción del "yo" y los "otros"; del "nosotros" y del "ustedes", "ellos". El desconocimiento de ese "otro" provoca la distinción ideal de lo idéntico y de lo diverso; "nosotros" estamos identificados por un conjunto de factores abstracto (a fin de cuentas, concretados) que sirven de paradigma para separarnos de los "otros" quienes no participan de lo que hemos creado y aceptan como identidad.

Entonces partiendo de ese desconocimiento del "otro", se lo considera un extraño, poseedor de un comportamiento raro, ajeno, por lo cual, se llega a considerar que aquel no pertenece a lo "nuevo" y se convierte en un extranjero. Cuando el "otro" se ve enfrentado a los "otros" se genera una doble reacción, por un lado, fascinación por lo diferente y por otro, aversión, miedo, rechazo a lo distinto, desconcertante, desconocido.

El "otro" es una incógnita que se resuelve, en muchos casos, con la adjudicación de características negativas: el extraño, el extranjero, el "otro" es quien provoca los conflictos, quien trae enfermedades, el ignorante, quien está equivocado, etc. Esta reacción se presenta tanto entre grupos humanos pequeños como en sociedades más grandes, en las que, en ciertos cosos, puede manifestarse en formas de nacionalismo exacerbado y discriminación hacas lo diferente (otras etnias, género distinto, edad, etc.).

El sentido identitario se va construyendo discursivamente, plasmándose en el lenguaje ("yo soy", "nosotros", "ellos", "otros"), que permite a las personas ubicarnos en un espacio social determinados, así como seleccionar los criterios éticos y normativas que rigen su conducta e integrar el pasado con el presente de un grupo específico. 
El sentido de identidad se va construyendo progresivamente, casi siempre motivado por estímulos exteriores. Por ejemplo, cuando un miembro del grupo es agredido, los demás, al sentirse solidarios, refuerza su sentido de pertenencia a la comunidad (pp. 94-97).

Sin embargo, hay que tener cuidado de no caer en un imperialismo cultural (Campo A., 2008), aun dentro del mismo grupo étnico o grupo social que comparte identidades emblemáticas casi estándares, ya que ello puede estar definido de forma consciente a nivel ideológico o político por grupos de poder o elites, atentando así contra su propia unidad como grupo social, no sabiendo tolerar las diferencias de las expresiones culturales. En el caso de la villa Ostumeña, se hace manifiesto este aspecto cuando se pone en perspectiva la masacre del cantón San José Carrizal, la cual se expresa como una pugna histórica que remueve odios e incomprensiones en la actualidad.

\section{El patrimonio cultural, símbolo de unidad identitaria y territorial}

Hope Ponce \& Mora Eguiarte (2000) definen patrimonio cultural argumentando lo siguiente:

Término que, de forma general y no muy precisa y con un origen incierto, se utiliza para denominar (y de esta forma ordenar y conservar) todas las cosas (sean paisaje, estructuras arquitectónicas o arqueológicas, valores étnicos, características bilógicas, costumbre y formas culturales, étnicas y demás) que se supone dan cuerpo y color a la historia y al presente de un grupo, pueblo, Estado y/o nación [...] El término (que deriva de parte y alude a partir) implica posesión o apropiación de algo y por medio de sus normativización, regulación y legislación, el derecho a su usufructo y explotación. [...] Para Hughes Varios, el término implica la revaloración de los bienes culturales del pasado y del presente como antídoto frente a la presión de la técnica y de la complejidad organizacional moderna (p. 134).

Para Campo A. (2008), el patrimonio cultural se expresa en:

la herencia material intangible colectiva, construcción sociocultural, que demuestra la capacidad creativa, espiritual, histórica y política de las organizaciones humanas, vinculando a las generaciones pasadas con las presentes y trazando valores comunes futuros. Considerar el patrimonio como construcción social implica que se genera dentro de los procesos culturalessimbólicos, muchas veces inconscientes, pero aceptados colectivamente. Es decir, no es un fenómeno "natural", sino que corresponde a procesos construidos por la sociedad humana, de acuerdo a un lugar y tiempo determinado.

Como en muchos aspectos de la representación social, el patrimonio obedece a cierta internacionalidad ideológica, económica, de utilización de los medios de ejercicio del poder. Por lo que, junto a las construcciones sociales del 
patrimonio, se halla una construcción de la presentación identitaria, que persigue la legitimación colectiva. Mediante la designación de ciertos aspectos se va estableciendo la imagen de una identidad, casi siempre, ideal. El rasgo principal del patrimonio como construcción social es, entonces, su capacidad simbólica, mientras su función es la de reafirmar una identidad, con expresión igualmente simbólica (pp. 127-128).

Partiendo de lo anterior, la presente investigación propone un trabajo de descripción y sistematización del patrimonio cultural, tanto tangible como intangible, y la construcción de las mentalidades individuales y colectivas a partir de los haceres y saberes, que a través de su historia se ha venido configurado en los ostumeños; una forma de autenticarse como el municipio de El Chorrerón, de la vista panorámica de su iglesia, que data del período colonial; las creencias en El Muluz y la existencia de otras cuevas que obedecen a otros seres mitológicos locales; es el lugar donde se cultivó el añil y el café, es la villa en don del Dr, Ancalmo inspirado le canta a "la niña de la piña" y a "las palancas", es el municipio que ha revitalizado la molienda y el cultivo de la piña, todo ello le confieren identidad cultural a los ostumeños.

\section{Las relaciones de género y el emprendimiento local}

El PNUD (2014) nos orienta, en términos de emprendimiento local de género, de la siguiente manera:

En El Salvador los desafíos de trabajar por la igualdad entre mujeres y hombres en algunos campos siguen siendo enormes. Por ejemplo, en la forma de cómo hacer negocios las mujeres tienen más dificultades para separar su economía familiar de la contabilidad empresarial, por la vulnerabilidad socioeconómica que enfrentan.

Entre otras limitaciones que encuentran a la hora de emprender un negocio se suman: barreras legales, menor disponibilidad de tiempo por las tareas domésticas y poco acceso a información para la formación empresarial y el desarrollo de emprendimientos (p. 1).

Conscientes de que en El Salvador se vive, hoy en día, una cultura androcentrista o patriarcal, y ello no es ajeno a Santa María Ostuma, y sin embargo, su práctica en la agricultura y su producto emblemático, la piña, le permite una relación entre hombres y mujeres compartida e integrada, se vuelve necesario revisar algunos conceptos al respecto.

Una cultura patriarcal, según Díaz (2003), citado en López Caña, Menjívar Leiva \& Meza Martínez (2015) afirma lo siguiente:

"Los procesos de vida, son procesos culturales y todas las personas son seres de cultura, aprenden cultura, generan cultura y viven a través de su cultura", de esta 
forma, ser hombre o mujer es resultado de todo un proceso psicológico, social y cultural a través del cual cada individuo asume su rol como perteneciente a un género... De igual manera, Ramírez (2010) atestigua: "Las personas, tienen la creencia de que muchos de los comportamientos, características, así como tareas y funciones que se le endosan a las mujeres y a los hombres tienen su razón de ser en el hecho de haber nacido... es decir, por ser de sexo femenino o masculino". Por consiguiente, actúan respetando criterios establecidos, que a su vez siguen siendo modificados y acoplados a su propio estilo de vida donde volverán a modificarse, haciendo de la cultura algo cambiante (p. 51).

En este sentido, Kottak (1996) afirma: "La gente hace suyo gradualmente un sistema previamente establecido y de símbolos que utiliza para saber su mundo, expresar sus sentimientos y hacer sus juicios, luego, este sistema les ayuda a guiar sus comportamientos y sus percepciones a lo largo de sus vidas" ... Las culturas se transmiten mediante el aprendizaje, la lengua y habla". Por tanto, se debe considerar la transmisión de cultura, valores y comportamiento en un grupo social determinado y que ello atraviesa por acentuar el tipo de relación de género.

Por otro lado, los Objetivos de Desarrollo Sostenible (2016), específicamente el objetivo 5 nos dice que hay que "lograr la igualdad entre los géneros y empoderar a todas las mujeres y las niñas"; y en la meta 5.5 hace referencia a "velar por la participación plena y efectiva de las mujeres y la igualdad de oportunidades de liderazgo a todos los niveles de la adopción de decisiones en la vida política, económica y pública".

Sin lugar a dudas, vamos a encontrar en el presente informe una participación equitativa en la legitimación de los constructos de los imaginarios colectivos e individuales culturales del municipio, que se expresa en una visión y práctica de equidad participativa de la mujer con respecto a los hombres en cuanto las tradiciones, costumbres y el emprendimiento de la piña localmente.

Es así, que la fusión de los conceptos género y emprendimiento será parte de los variados papeles que cumple la mujer ostumeña; y que se encuentra entrelazado en los diferentes apartados del presente artículo.

\section{Método}

\section{Participantes}

Los participantes claves de esta investigación fueron los directores o los responsables de referentes institucionales, municipales, culturales y productivos del municipio, así como artista locales, comerciantes, feligreses y responsables parroquiales, la "cuenta historias" local, el curandero, las rezadoras y los fabricantes de candelas, entre otros. 


\section{Diseño y tipo de estudio}

El método es de tipo cualitativo con enfoque etnográfico, que, tal como Pérez de Tudela (2012) lo explica:

(Del griego $\square \square \mathbf{v o} \square$ : “etnia", y $\square \square \square \square \square$ : "escrito") es la parte de la antropología cultural que se ocupa (observa y describe) de los distintos aspectos de una cultura o un pueblo, lo cual incluye todo: sus costumbres, los medios de vida, el idioma, la población, la alimentación, la vivienda, la economía, la división del trabajo, los esquemas producción y un tan largo etcétera como se quiera. Consiste en la recolección de datos in situ y teniendo como informantes a los integrantes de esa realidad. Los datos recopilados consisten en la descripción densa y detallada de sus costumbres, creencias y mitos, genealogías e historia, etcétera, dicha información se obtiene mayormente por medio de largas entrevistas con miembros de la comunidad o informantes claves de ellas (p. 312).

Desde esa perspectiva, se ha logrado documentar el patrimonio cultural tangible e intangible, las historias locales, sus leyendas y tradiciones, así como la organización social a partir del trabajo agrícola y comercial, el papel de la mujer ostumeña, así como su religiosidad y espiritualidad; todo ello mediante la recolección de datos en entrevistas semiestructuradas y grupos focales, donde el registro fotográfico, el uso de la cámara y el drone dan un fiel reflejo del municipio ostumeño.

Se realizaron 17 visitas de campo. La movilidad del equipo de investigación al interior del municipio se realizó en transporte de la Utec y por la alcandía.

\section{Instrumento de recolección de datos}

Para la recolección de datos fue necesario generar instrumentos previos aplicados a entrevistas semiestructuradas e instrumento para grupo focal, ficha de registro de patrimonio tangible y ficha bibliográfica, todos ellos sometidos a juicio de expertos para mejorar su condición y ser lo más eficiente en la obtención de los datos.

Lo anterior fue posible gracias a la implementación de aplicación de muestra en cadena o por redes (bola de nieve) con la que, según Hernández Sampieri, Fernández Collado \& Batista Lucio (2014), nos dice: "Se identifican informantes claves y se agregan a la muestra, se les pregunta si conocen a otras personas que puedan proporcionar más datos o ampliar la información (Morgan, 2008), y una vez contactados, los incluimos también" (p. 388). Para el caso concreto de Santa María Ostuma se buscaron líderes y lideresas locales que respondieran a las necesidades de información que requería la presente investigación; y ellos nos dieron nombres de nuevos informantes, los cuales se adicionaron a la muestra. 


\section{Procedimiento}

\section{Consulta de fondos documentales}

Se realizaron consultas de fondos documentales propios y municipales, en las universidades y librerías. Se encontró una referencia documental monográfica de 1996 escrito por el coronel Aquilino Díaz, que es el único documento que narra acontecimientos de la guerra de 1980 a 1992, así como un recorrido por las actividades socioculturales del municipio en esos años antes de los terremotos del año 2001. Esta fue una excelente iniciativa del coronel Díaz, dado que su registro permite comprender la historia de la villa ostumeña.

Además, la presente investigación se apoyó en informes y trabajos propuestos por ONG y organismos de cooperación internacional, tales como los siguientes:

- Política municipal de protección Integral de la niñez y de la adolescencia de Santa María Ostuma, vigente del 2016 al 2020, esfuerzo encaminado por la OIT, Educo y la alcaldía municipal.

- Revista Onpaku (2015) apoyada por la Agencia de Cooperación Internacional del Japón, la Comisión Nacional de la Micro y Pequeña Empresa (Conamype), la estrategia de desarrollo económico local "El Salvador Un Pueblo Un Producto" y la alcaldía municipal de Santa María Ostuma; facilitada por Nahún Tamayo.

- El programa de las fiestas patronales 2017 y el del año 2018 de Santa María Ostuma en honor a la Virgen de Candelaria, que resultan ser fuentes de información actualizadas de proyectos de desarrollo local y de la vivencia sociocultural ostumeña.

\section{Observación directa}

A partir de las visitas de campo, se mantuvo un diario de campo en donde se registraba la información de la cotidianidad de los habitantes de Santa María Ostuma: en los funerales, en los días de producción agrícola, como los yucales, la corta de piña, y la molienda; en las fincas ecoturísticas, en las visitas a los centros de salud y educativos, tanto a en el ámbito del casco municipal como en el de los cantones.

\section{Entrevista semiestructurada}

Se realizaron 27 entrevistas semiestructuradas focalizadas, desarrolladas en un entorno de confianza en el que los entrevistados alcanzaron a profundizar 
con sus repuestas a las preguntas que se le plantearon en el instrumento previamente elaborado.

\section{Grupos focales}

Los grupos focales se lograron a partir de una convocatoria de los funcionarios de la alcaldía municipal a los líderes y lideresas de los diferentes cantones del municipio, que, mediante las habilidades del dialogar, tenían el propósito de registrar su realidad y experticia en torno a los diferentes tópicos de la investigación.

Fueron 7 grupos focales los que se desarrollaron: 3 con estudiantes del bachillerato, 1 con profesores del Instituto Nacional de Santa María Ostuma, y 2 con líderes y lideresas de los cantones del municipio; y un grupo focal con familiares de víctimas de la masacre del cantón San José Carrizal.

\section{Procesamiento de la información}

\section{Aplicación de software Nvivo 11 para análisis de resultados}

Como equipo de investigación, se optó por aplicar, para el análisis de resultados, el software especializado Nvivo 11. Este análisis permitió codificar, mediante análisis de significados, los conceptos y las ideas más comunes que yacen en el imaginario colectivo de los informantes claves entrevistados, quienes fueron principalmente líderes y lideresas de asociaciones de fruticultores, jóvenes del Instituto Nacional de Santa María Ostuma, referentes municipales y religiosos, y comerciantes, entre otros.

\section{Triangulación de fuentes de datos}

Navarro Ardoy, Pasadas del Amo \& Ruiz Ruiz (2014) nos orientan con respecto a la triangulación:

Denzin (1970) define la triangulación en investigación como "la combinación de dos o más teorías, fuentes de datos o métodos de investigación en el estudio de un fenómeno singular". Según el aspecto en el que se adopte la estrategia de combinación se puede hablar de: 1. Triangulación de fuentes de datos que consiste en la consideración del punto de vista de los distintos grupos que conforman la realidad objeto de estudio... (p. 2)

Partiendo de lo anterior, en la presente investigación se hace un ejercicio de triangular varios de los apartados de los resultados de campo; más en aquellos temas que se vuelven de gran relevancia histórica y patrimonial cultural. 


\section{Registro fotográfico y uso de drone}

El recurso fotográfico ha permitido evidenciar mediante imágenes el patrimonio tangible edificado, en el cual se destacan la iglesia de la Virgen de Candelaria, el polideportivo municipal, los vestigios del beneficio de café; fotografías de moliendas y sus respectivos trapiches; de producción agrícola en general, de edificaciones de dispensarios de salud, templos religiosos y de centros educativos a nivel de casco municipal y cantonales, entre otros.

Además, la Vicerrectoría de Investigación y Proyección Social de la Utec facilitó técnicos y el recurso del drone, que posibilitó en 9 horas de trabajo continuo tomas aéreas de El Chorrerón, el mirador y la iglesia parroquial, entre otros, que son lugares turísticos emblemáticos del municipio.

\section{Fotografia 1}

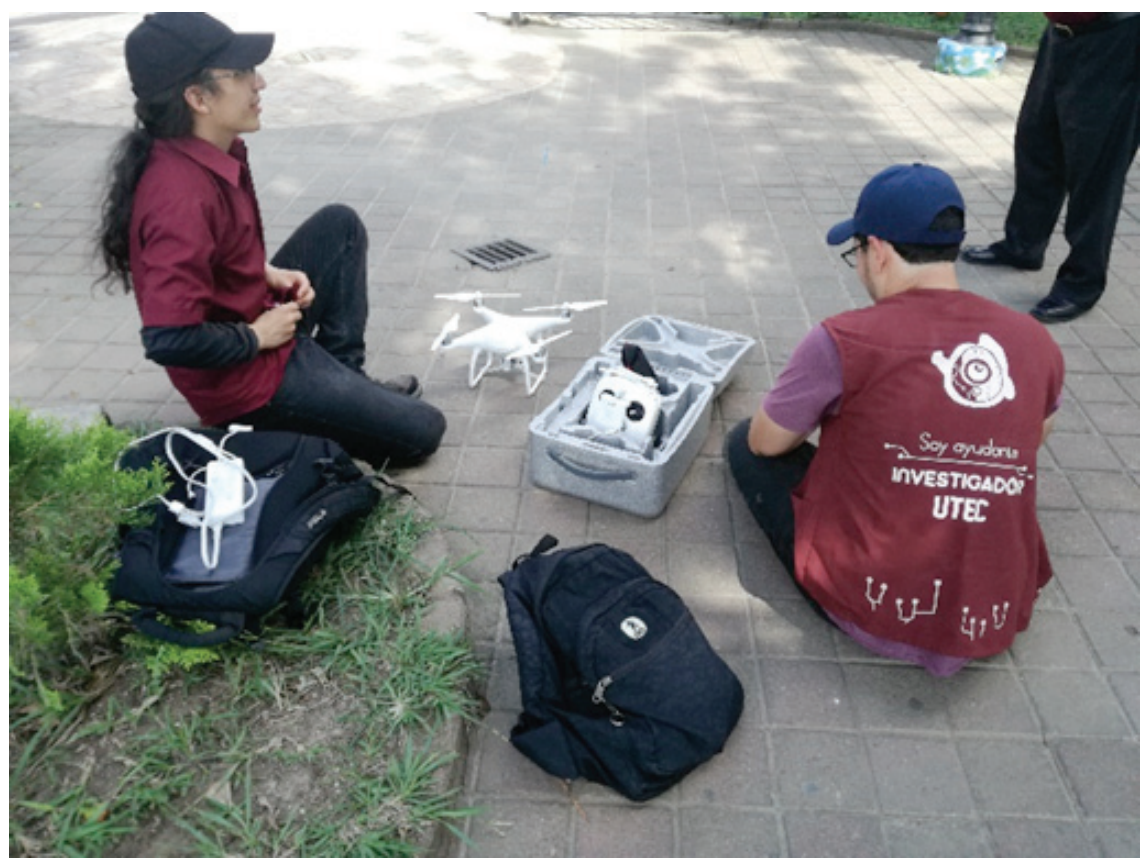

Uso del drone por eng. Ronny Cortez, para tomas aéreas en el municipio de Santa María Ostuma. (Fotógrafo: Carlos Osegueda. 25 de agosto de 2017)

\section{Análisis de resultados de investigación}

Los resultados de la investigación están dados a partir de la consulta previa de fondos documentales, así como banco de videos en Online, además la aplicación 
de las entrevistas semiestructuradas y los grupos focales, que se realizaron en el trabajo de campo.

\section{Vivencias locales entorno a la Piña Ostumeña}

\section{Figura 1}

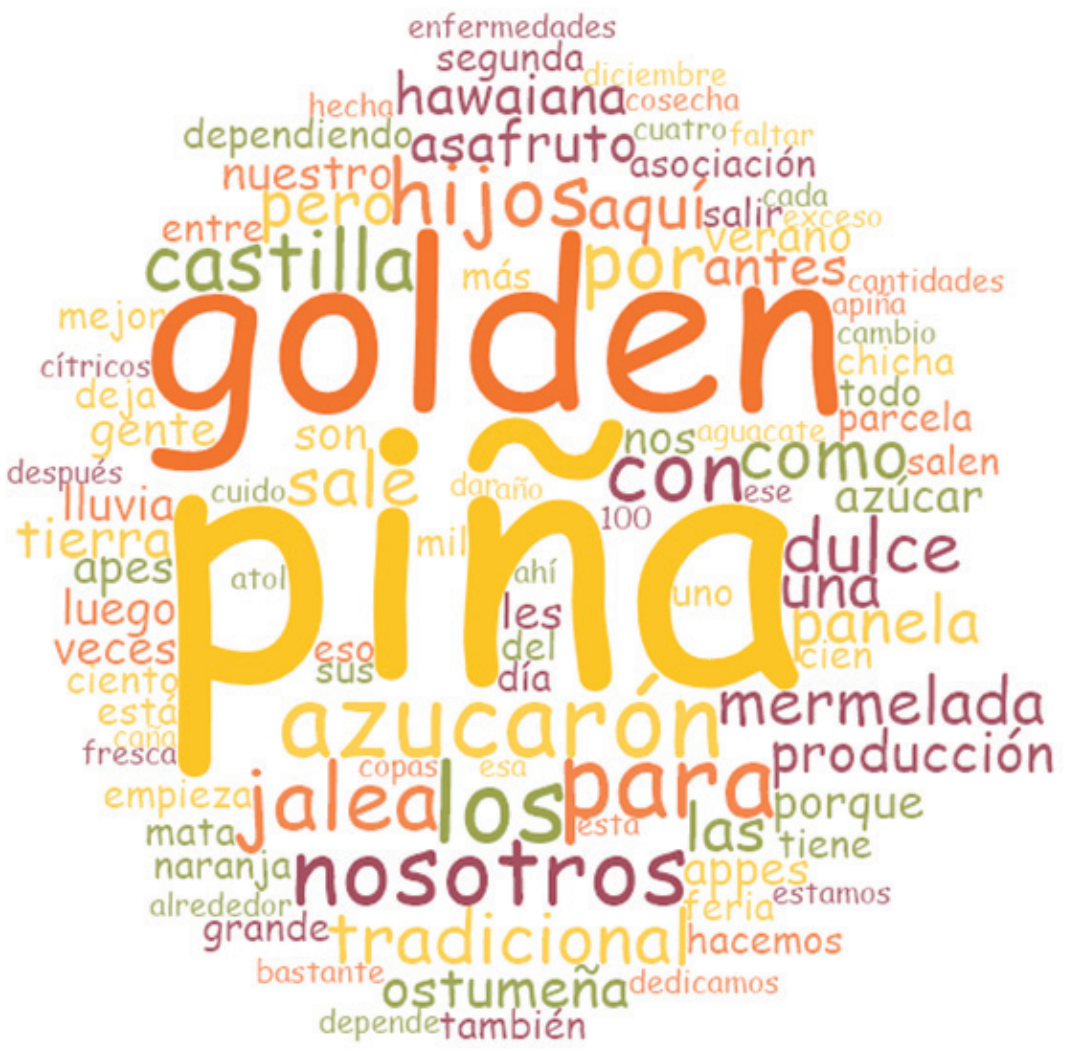

Palabras más frecuentes de coincidencias exactas sobre la productividad agrícola y roles de Género en Santa María Ostuma.

La nube de palabras nos describe que dentro de las opiniones de los entrevistados es la piña el producto por excelencia en el municipio, destacando las variedades de la misma como son la piña Golden, la piña de azucarón, la piña de castilla y la hawaiana ; se manifiesta las diferentes procesamientos de la fruta como es la chicha, las mermeladas, además expresan los tiempos de cosecha (verano e invierno) y en menor medida entrelaza este producto con la organización social local entorno al fruto (ASAFRUTO y APPES). 
Santa María Ostuma es conocida a nivel nacional como "la Tierra de la Piña", dicho título se debe a que es uno de los mayores productores del fruto, en sus diferentes cultivares, lo cual posiciona a los productores ostumeños como los referentes a nivel nacional; inclusive a nivel de la región de los nonualcos, representa para ellos su patrimonio natural y cultural. En ese sentido se presenta el siguiente dato a nivel nacional sobre la distribución, registrada por Sandoval \& Torres (2011), investigadores del Programa MAG -CENTA Frutales, en el siguiente fragmento:

En El Salvador el área sembrada de piña es de aproximadamente $650 \mathrm{mz}$, distribuidas en las zonas piñeras por tradición: Santa María Ostuma, Ciudad Barrios, Chalchuapa, Cojutepeque y Jiquilisco. La producción en estas zonas no es suficiente para satisfacer la demanda nacional, volviendo necesario mejorar las técnicas de manejo e incrementar las áreas de siembra. (Pág. 4)

Tomando en cuenta la referencia a nivel nacional del MAG-CENTA, es necesario el contexto histórico de los cultivares de la piña ostumeña, sobre las experiencias de vida, entorno al patrimonio natural y cultural de los Ostumeños, para dimensionar del porqué del título de la "Tierra de la piña", desde sus posibles orígenes en dicho municipio nonualco:

Las 3 variedades que supuestamente trajeron los españoles que son: la de Azucarón, la de castilla y la de agua nada más esas existían cuando yo era cipote no había otra $[\ldots]$ hoy con la famosa tecnología me imagino que han sido clonadas algotras variedades [...] pero aquí en el municipio solo se conocían 3 variedades: las de castilla, las de Azucarón y las de agua [...] aquí hay algunos profesionales que no se saben explicar esto [...] pero yo concluyo que la semilla de la piña vino para acá cuando se dio la famosa transacción de productos españoles [...] El Salvador entonces viéndolo así, España tiene una provincia que se llama Castilla entonces de ahí deduzco que se dio en ese entonces, la traída de la semillas y fue así como algunos nuestros antepasados comenzaron a sembrar la piña [...] pero solo aquí en Ostuma es que quizás trajeron $[\ldots]$ porque ya en otro pueblo indígena no hay $[\ldots]$ solo he visto allá por donde nació este monseñor, el que es santo como se llama [...] Romero [...] ahí he visto pero solo de castilla colgando en las peñas [..] ahí está la piña pero solo ahí $[\ldots]$ yo fui a una excursión con un grupo de caficultores, como era presidente de la asociación de cafetaleros de la paz [...] fui y vi montón de piñas colgando ahí $[\ldots]$ si cree que uno que solo aquí pero no [...] ese pueblo donde nació Romero. (Diaz A., 2017) 


\section{Fotografia 2}

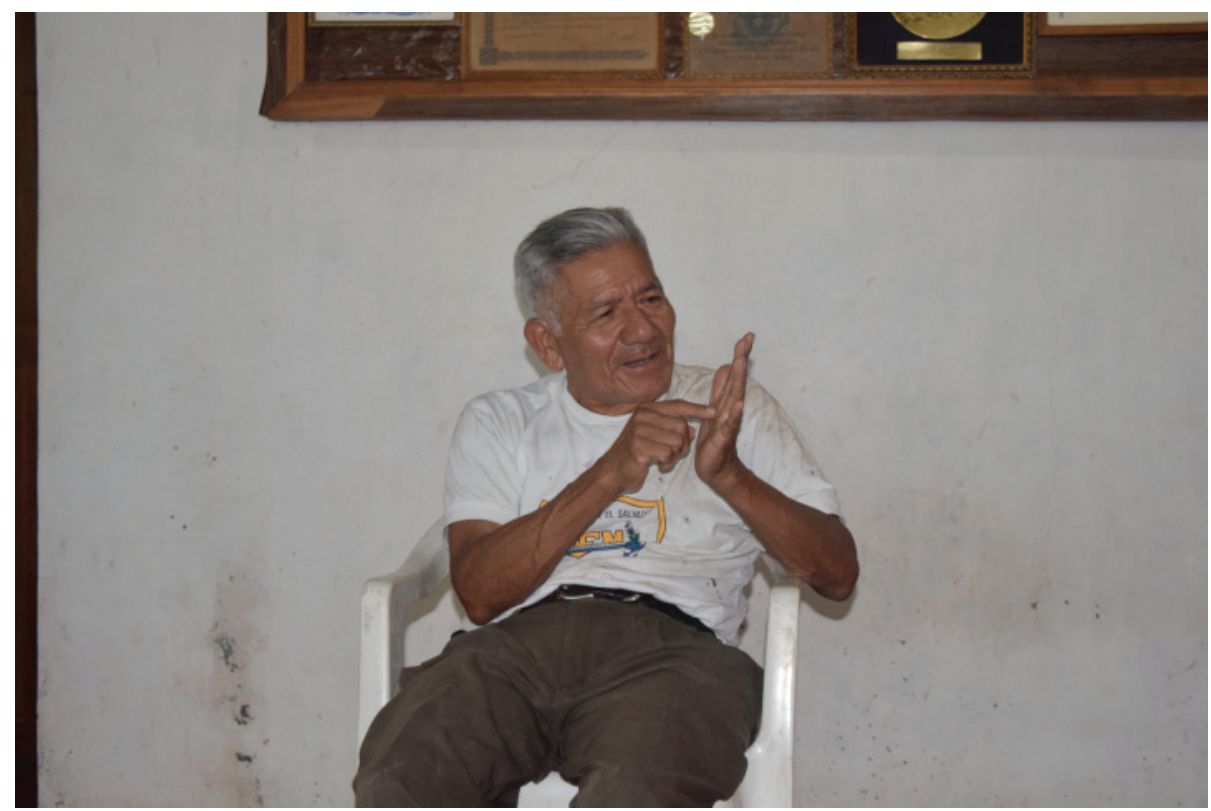

Entrevista guiada con el Cnel. Aquilino Díaz Hernández, quien aporto desde su monografía escrita de 1996, elementos historiográficos de los ostumeños. Realizada el día 27/06/2017, fotografía tomada por Miguel Ángel Hernández Vásquez.

Es importante resaltar el trabajo interinstitucional que, a nivel local, los agricultores o mejor dichos los fruticultores ostumeños, desarrollaron como parte de la aplicación de los nuevos conocimientos adquiridos a través de la asesoría técnica de profesionales agrónomos, tal como se manifiesta a continuación:

¡La primera piña Golden aquí nosotros la sembramos (en el) dos mil tres, dos mil cuatro! Una parcela demostrativa la sembramos de la cancha de fútbol, a donde está ASAFRUTO, al otro lado en un terreno, ahí la sembramos. el proyecto de Eloísa estaba directamente para la reproducción de semilla, pero, ya en campo nosotros estábamos viendo de que queríamos ver el fruto, entonces, Panamá de Pretela, ella nos asesoró para la producción de semilla, pero le dijimos que queríamos ver el fruto, queríamos la mitad, el cincuenta por ciento, entonces el cincuenta por ciento de la semilla y la otra mitad de la fruta ya producto verdad.[...] Lo bueno es de que nosotros bien tengo en mente que, empezamos a sembrar el cuatro de mayo de dos mil tres; parece que andaba tu papá ahí también (señala a un tercero). El cuatro de mayo del dos mil cuatro nosotros estábamos cortando las primeras piñas, de un tamaño de unas ocho o nueve libras; jel punto está en que la (piña) tradicional tarda dieciocho meses o a los dos años, esa (la Golden) no a los doce meses!, eso ya nos gustó verdad! empezamos y seguimos y seguimos trabajando. (Beltrán Panameño, 2017) 


\section{Fotografia 3}

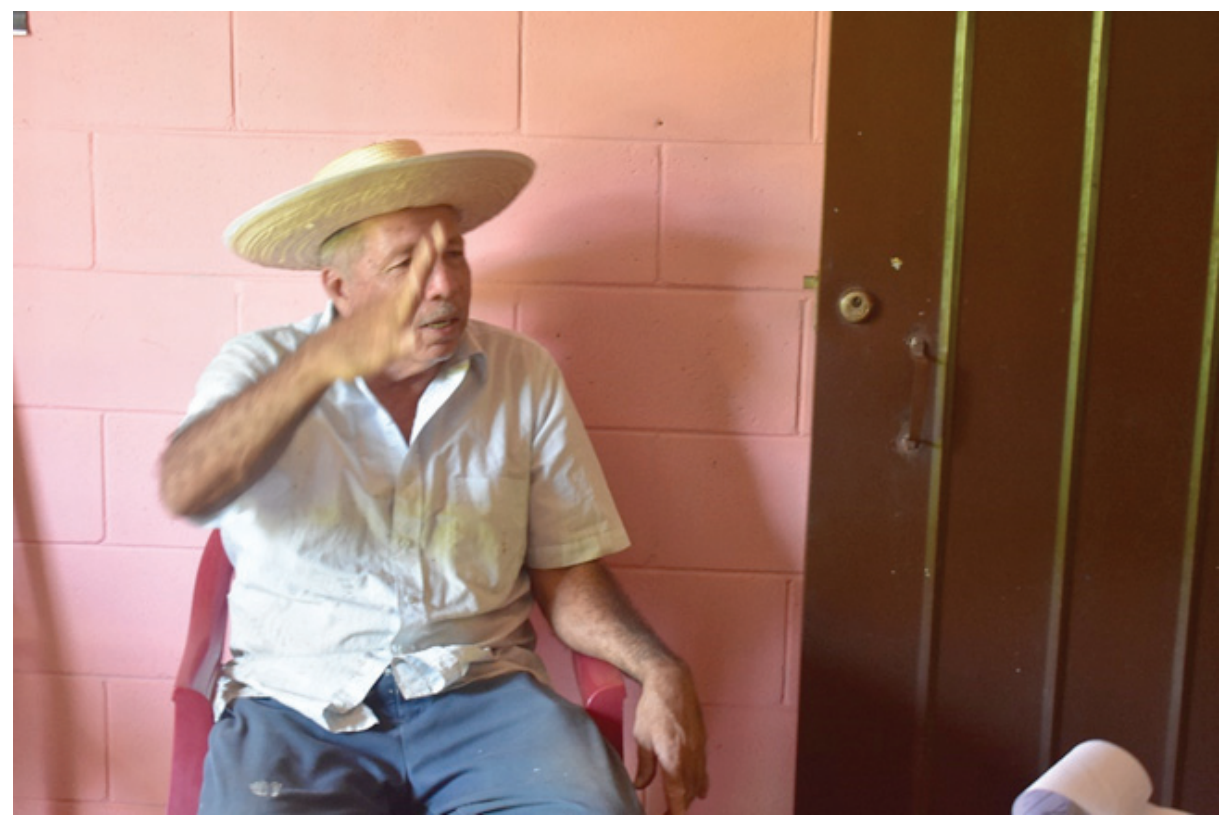

Entrevista guiada con don Salvador Beltrán Panameño. Productor de Piña Golden. Realizada el día 29/06/2017, Fotografía tomada por Lisbeth Quinteros.

Por otro lado, como parte de las oportunidades hacia las nuevas generaciones, que se han desarrollado a nivel local, a partir del fortalecimiento e intensificación del cultivar Golden (MD-2), se logró evidenciar el proceso de recolección del cultivar Golden, por parte de Nelson Eduardo López, de 25 años, un joven productor independiente a las organizaciones locales, entre ellas ASAFRUTO y APPES, como los dos referentes locales que aglutinan los fruticultores de la piña ostumeña.

Al joven se le abordó en su breve espacio de descanso, para comprender la dinámica de trabajo que él realiza, en cuanto a la recolección y comercialización de la piña que recolecta en las mañanas; él comentó que es propietario del cultivar que representa media manzana de terreno cultivada, y que el dueño del terreno es su abuelo paterno, además dio datos muy relevantes sobre la forma del cultivar, en cuanto a su proceso de inducción para acelerar su maduración, esto como parte de la manipulación genética, que permite el control de la fruta, en cuanto a su productividad; por otro lado, comentó sobre el manejo y control de las plagas y enfermedades, que atacan a la piña, y como ellos, desde la 
asistencia técnica de agrónomos del CENTA, han logrado desarrollar el control de las mismas, desde la aplicación de tecnología agrícola.

Con respecto a la comercialización de la piña nos informó que él lo hacía directamente con los vendedores de los grandes mercados de San Salvador, específicamente del Mercado Central y la Tiendona, y que de ello se encarga su esposa Fátima Méndez, también ostumeña de nacimiento. Esto evidencia el emprendedurismo local, de una pareja de jóvenes esposos, quienes se han empleado como productores y comerciantes de la piña ostumeña.

\section{Fotografia 4}

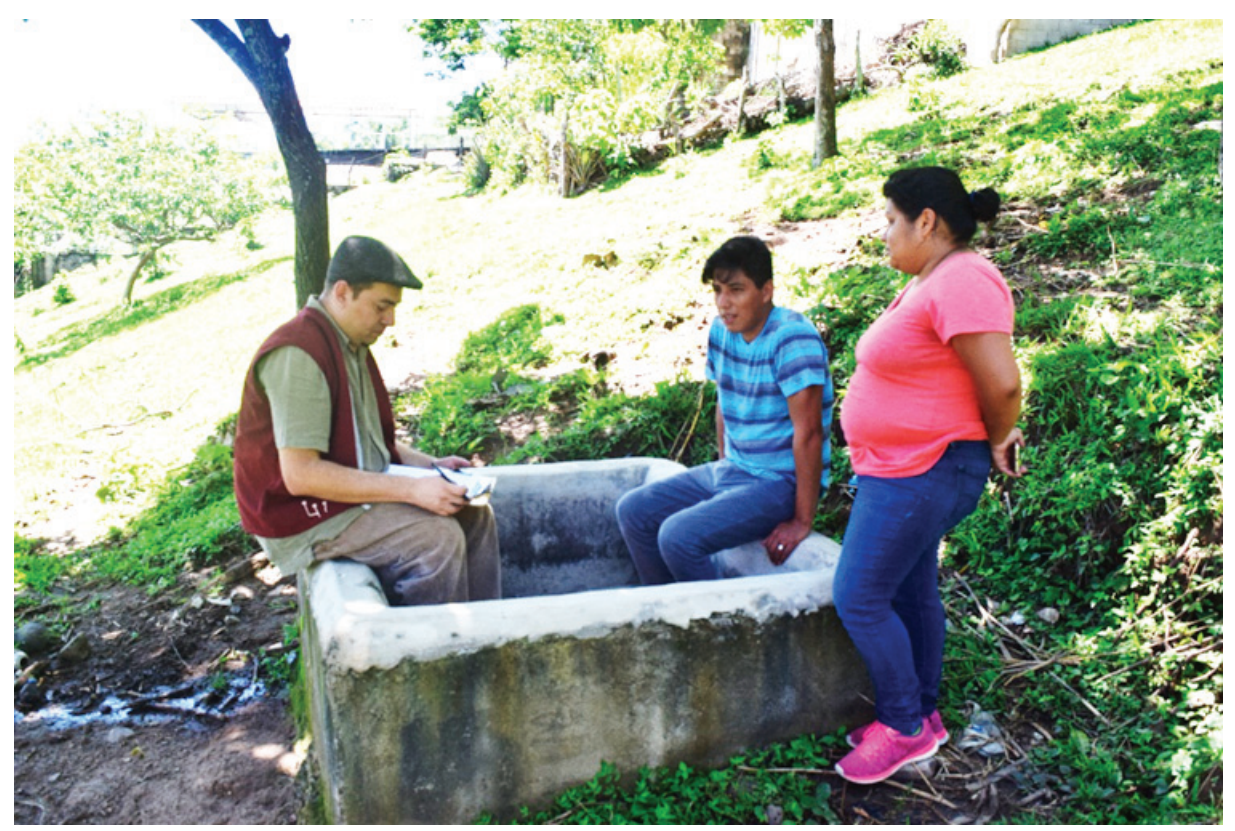

Entrevista guiada con Nelson López y Fátima Méndez, jóvenes esposos y productores independientes de la Piña Golden. Entrevistador: Miguel Ángel Hernández Vásquez. Fotografía tomada por Mauricio López, el día 20/07/2017.

En palabras de Felicito Cerón (2017), otro productor de la piña ostumeña conocido localmente como Don Chito Mejía, comerciante y dueño de la Finca Ecoturística Santa Elena, ubicada en el Cantón San José Carrizal, destaca los periodos de siembra y cosecha en el siguiente aporte:

Desde abril, todo mayo, junio y hoy vamos con julio, esos 3 meses están saliendo piña de invierno y ya la otra cosecha da en noviembre, pero desde sep- 
tiembre ya está saliendo la de castilla, hasta diciembre que es la feria de la piña. (Chito Mejía, 2017)

\section{Fotografia 5}

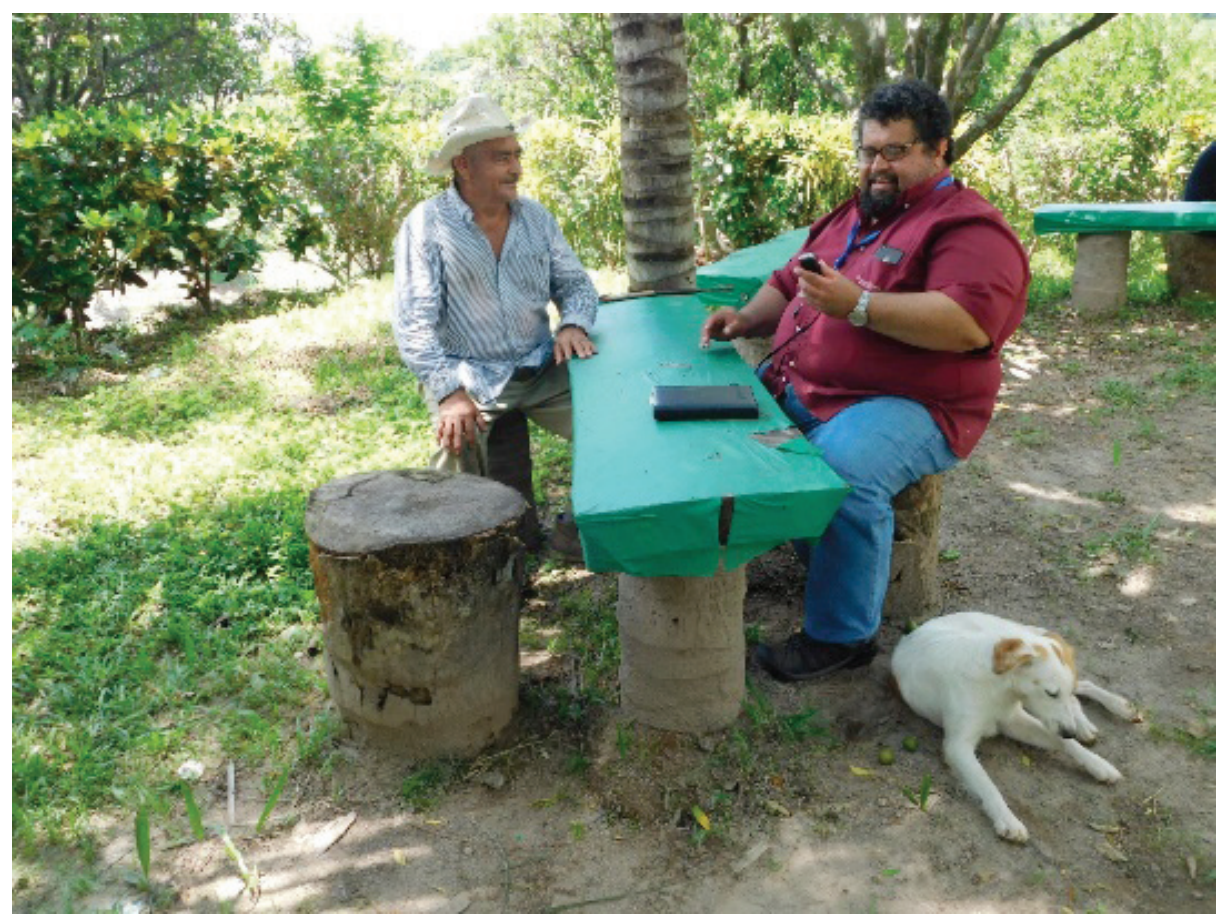

Entrevista guiada con Felicito Cerón, conocido como Don Chito Mejía, en finca Ecoturística Santa Elena. Entrevistador: Mtro. Carlos Osegueda.

Fotografía tomada por: Francisco Santos Alvarenga el día 11/07/2017.

Lo anterior, permite rearfirmar que con el impulso de recorridos en fincas ecoturisticas, productores independientes, asociaciones de fruticultores y la adopción de tecnología para mejorar la productividad del fruto, se impacta de forma positiva en la generación de un circuito productivo y de comercialización que aviva una dinámica sociocultural en torno al producto agrícola insignia "la piña" dándole así, un sentido identitario, individual y colectivo, a la villa ostumeña.

Ritualidad, tradición y costumbre en Santa María Ostuma 


\section{Figura 2}

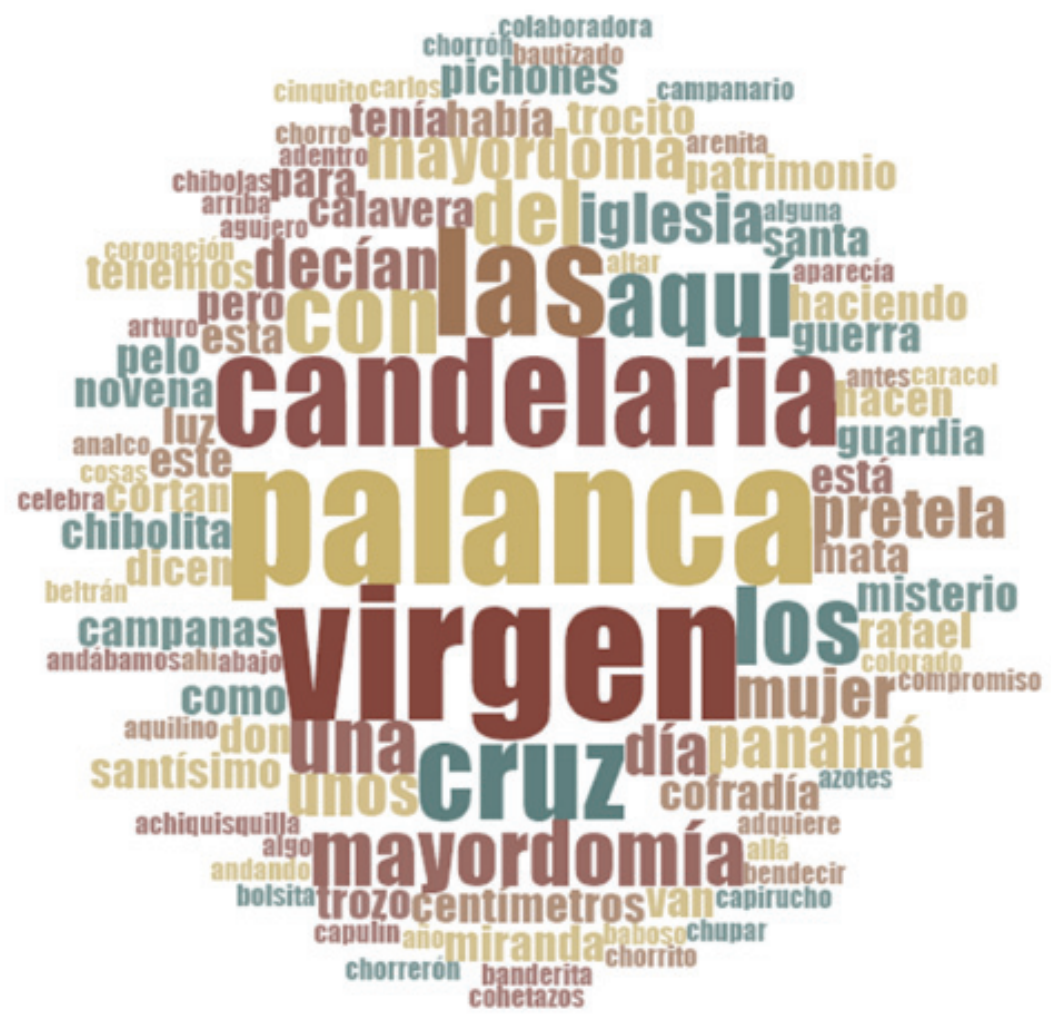

Se puede apreciar que dentro la nube de palabras respecto a la religiosidad y la espiritualidad de la villa ostumeña se pone de manifiesto las mentalidades de los entrevistados, resaltando la gran devoción a la virgen de Candelaria, que en el imaginario individual y colectivo se mantiene latente y llena de gran fervor católico a sus pobladores, entorno a ella, hay un sin número de manifestaciones de fe y de organización social que se van entrelazando, como por ejemplo las mayordomías, cofradías, las romerías, el sonar de campanas, la fabricación de pichones, las rezadoras, los templos y se expresan las historias como la calavera aparece para cumplir promesa, y que se encontraba atrás del altar mayor de la iglesia, todo ello como parte de las leyendas locales entorno a la religiosidad popular. 
Otro elemento que sobresale son las famosas palancas, acompañados por los viejos de mayo y las entradas de las flores de mayo, que llena de orgullo a la villa, y hasta se jactan de ser la más grande que se monta en el territorio salvadoreño, con más o menos 15 metros de largo la que se realizó en el año 2017; todo ello se desarrolla en el marco del día de la cruz y la fertilidad y el ciclo de la vida, así lo expresaron los ostumeños.

\section{El Patrimonio Cultural: la virgen de candelaria en la tradición oral y la espiritualidad ostumeña.}

Santa María Ostuma, resguarda en su templo parroquial, una de las imágenes de mayor devoción de la religiosidad popular latinoamericana como es la fiesta de la Candelaria en México, la cual en el concepto de la fiesta de los santos, gira entorno a la imagen del niño Dios, pues en México, la tradición del día de la candelaria es vestir la imagen del niño Dios que se encuentra en los pesebres caseros y son llevados a las parroquias para ser bendecidos; en El Salvador la tradición o fin principal del día de la candelaria es poder obtener la candela bendecida de la virgen ya que servirá como socorro para los momentos más difíciles. A estas prácticas religiosas la institucionalidad de la iglesia católica, los ubica dentro de la estructura de "Sacramentales", los cuales buscan santificar la cotidianidad de los fieles, a través de prácticas de religiosidad popular.

Al resguardo de dichas uniones entre lo divino y lo humano pueden percibirse dentro del sistema de cargo de organizaciones tradicionales llamadas cofradías; tal es el Caso de Santa María Ostuma que posee la cofradía de la virgen de Candelaria que es una de las más importantes en el pueblo, Santiago Montes (1977) nos propone que "la cofradía es una reunión de fieles que, con aprobación del ordinario, se rige en las iglesias para auxiliar al clero en sus sostenimiento y contribución a la suntuosidad del culto".

Cabe destacar que la cofradía la conforman las personas que hacen vida la celebración de un Santo en Particular y dentro de ellos se genera un socorro mutuo, más sin embargo, la cofradía no puede sostenerse por sí sola sin la persona destinada al cargo de Mayordomo, el cual se encarga del resguardo y la organización de la fiesta al santo que tiene a su cargo, dicha función puede ser heredada de generación en generación, es una responsabilidad en tiempo, de fungir como mayordomo.

La interpretación iconografía que presenta la imagen de la virgen de Candelaria; presenta particularmente como insignia, una vela en su mano derecha la cual representa la luz que ofrece su unigénito tal como proclamó el viejo Simeón, Deysi Candelario (2017), comentó al respecto: 
La virgen de candelaria representa la luz, que es la luz de cristo, porque el 2 de febrero, ese día, se conmemora la presentación del niño Jesús en el templo, luego de 40 días desde que nace el niño, las mujeres eran purificadas al hacer ese acto de presentación, entonces la virgen de la candela, es la luz de Jesús, por eso es la virgen de la candela .si ustedes ven la imagen que está en la iglesia en su mano esta una candela y en la otra tiene al niño Jesús.

Dicha candela forma parte del imaginario colectivo, integrando distintas dinámicas dentro de la tradición salvadoreña, la primera es la relación de la candela que porta la Virgen de Candelaria como salvadora de los pescadores, navegantes o náufragos, ante las tempestades, así como la acción intercesora de la candelaria ante los difuntos.

\section{Fotografia 6}

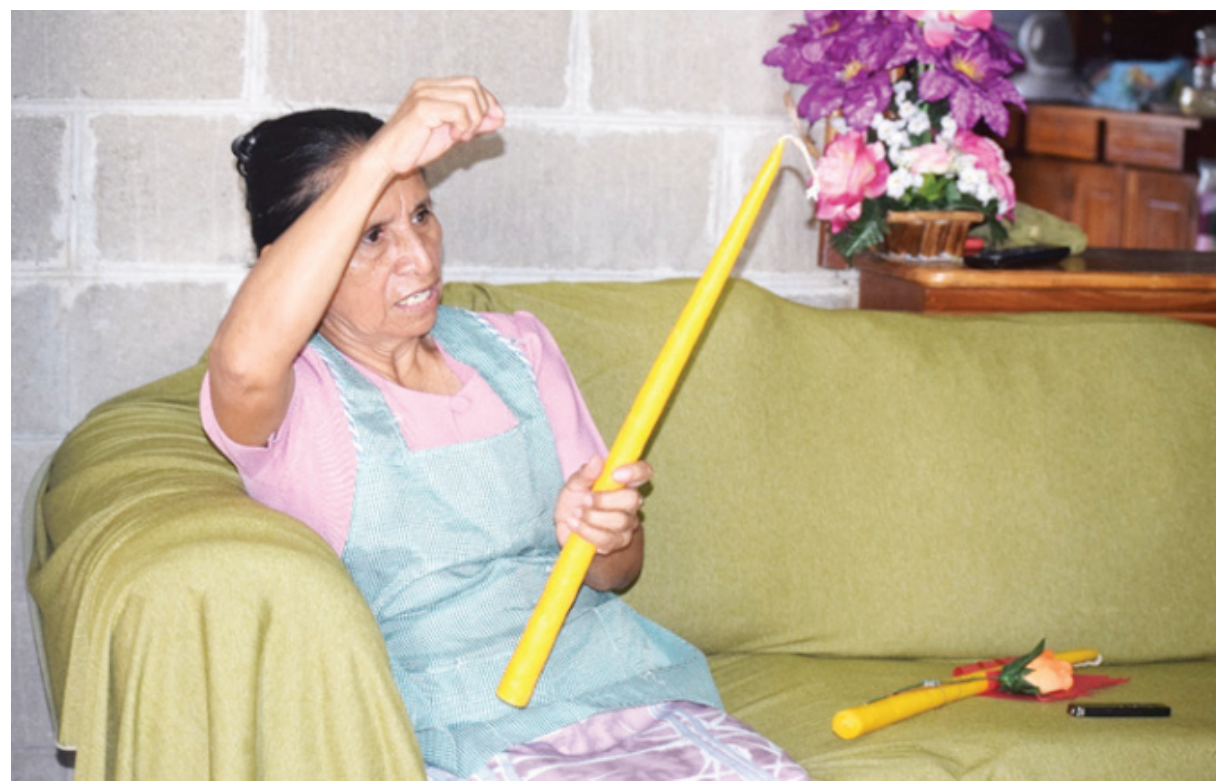

Doña Evangelina Tejada viuda de Anaya, explicando al equipo investigador el simbolismo y significados de la Candela para la feligresía católica de Santa María Ostuma. Fotografía tomada por Miguel Ángel Hernández Vásquez, el día 17/08/2017.

La función de la Candela de la virgen, representa el auxilio de sus devotos para apaciguar las grandes tormentas que asechan, o presentan un riesgo a su existencia y a la de sus sembradillos, elementos que comenta la señora Evangelina Tejada (2017), especialista en el arte de la hechura de velas para los actos religiosos de Santa María Ostuma, en el siguiente, argumento: 
Fíjese que aquí la gente la utiliza para cuando hay esas tormentas fuertes que hasta se va la luz, encienden la candela con fe, para que se quite la tormenta o cuando hay enfermitos, se le enciende la candela porque ya esta bendita.

La celebración de las fiestas patronales en honor a la Virgen de Candelaria, las cuales se celebran del 23 de enero al 2 de febrero, situándose en dicha festividad, los siguientes elementos muy similares a los "dones" que Marcel Mauss hace referencia sobre ese intercambio de bienes materiales e inmateriales, tal como se muestra en el siguiente relato:

Es una reliquia que se da, esa es como dicen, es el signo de que uno tiene esa fe y por medio de esa fe, es que la gente colaboramos en llevar la limosna, esa es la insignia que dan, meten un tamalito en una bolsita, un pedacito de marquesote y la banderita con una bolsita y cuando ya no alcanza eso, lo que se le da es una reliquia. Es como de seda, clarita, es un listoncito, pero ahí lleva escrito y dice: fiestas patronales en honor a virgen santísima nuestra señora de candelaria (Pérez de Aguillón \& Aguillón López, 2017)

\section{La mayordomía y cofradía ostumeña}

Para realizar la celebración de las fiestas patronales en honor a la Virgen de Candelaria, previo a la celebración de la fiesta patronal, se hacen visitas de casa en casa por parte de la mayordomía, para solicitar una ofrenda a la Virgen de Candelaria y a San José, en donde la participación de la comunidad en todo el proceso ritual, se ve expresado, como describe en el siguiente relato:

Sé que inicia del 23 de Enero al 2 de febrero, todos los sábados o cada 15 días pasan por un sector, entonces, por ejemplo si llegan a mi casa, vengo y les doy una ofrenda, entonces ellos como respuesta al apoyo que les da la población, van para la fiesta el 22 de enero, ese día por la tarde llevan la imagen de la Virgen de Candelaria con San José, la llevan hasta donde está la cofradía, con los mayordomos, hacen el acto de que llegan los Santos, le elaboran un altar, porque en la noche es el rezo, es ahí donde comparten con toda la gente que llega, los tamales, el café y el pan, se hace un rosario a la Virgen y luego se entregan los tamales a todos los que participan. (Candelario de Reyes, 2017) 


\section{Fotografía 6}

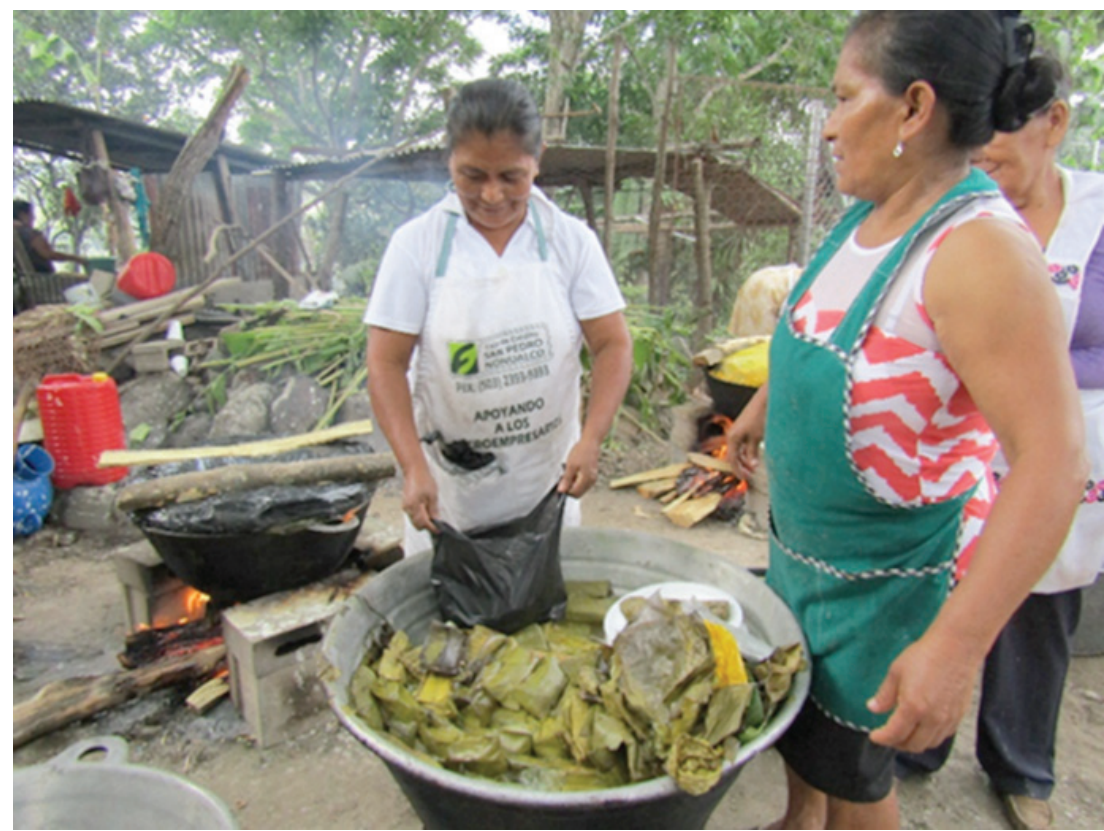

Repartición de tamales en una de las cofradías de Santa María Ostuma, cortesía de Deisy Candelario de Reyes.

Deisy Candelario (2017) describe el ritual de como se le ofrenda a la Virgen de Candelaria a través de las cofradías:

El día de la cofradía, cuando uno llega, ya la virgen está en su altar, entonces ahí hay una canastita también, y ahí están los mayordomos [...] entonces usted llega y deposita nuevamente una ofrenda a la virgen, entonces al depositar la ofrenda se le entrega como en agradecimiento una bolsita de papel manila, adentro van unos tamales ya tostados y pan con las banderas que se pusieron en los pichones, con una florcita [...] y lo invitan a que uno pase donde hay mesas, donde la gente coloca vasos con fresco, [...] en el centro están las bandejas con pan, entonces uno puede pasar a las mesas a tomar fresco y pan las veces uno quiera [...] si uno no va a dejar la ofrenda uno tiene la libertad de ir directamente a las mesas y uno puede tomar de lo que hay, entonces se preparan para grandes cantidades de personas y todos los tamales los han entregado en el rezo [...] y reparten a los vecino o los tuestan para echarlos a las bolsitas $[\ldots]$ ahí llega bastante gente a colaborar. 


\section{Las palancas ostumeñas, practica cultural y de arraigo identitario}

Cada municipio de la región nonualca tiene sus particularidades entorno a sus identidades culturales; en donde las tradiciones y costumbres juegan un papel vital para la integración de las mismas; partiendo de su legado ancestral, de su historia de héroes y mártires, así como su contexto presente, con la mirada hacia el futuro que robustece su rostro identitario, a través de sus actividades cotidianas, de su agricultura, gastronomía y estructuras sociales, que configuran su imaginario colectivo e individual.

\section{Fotografia 7}

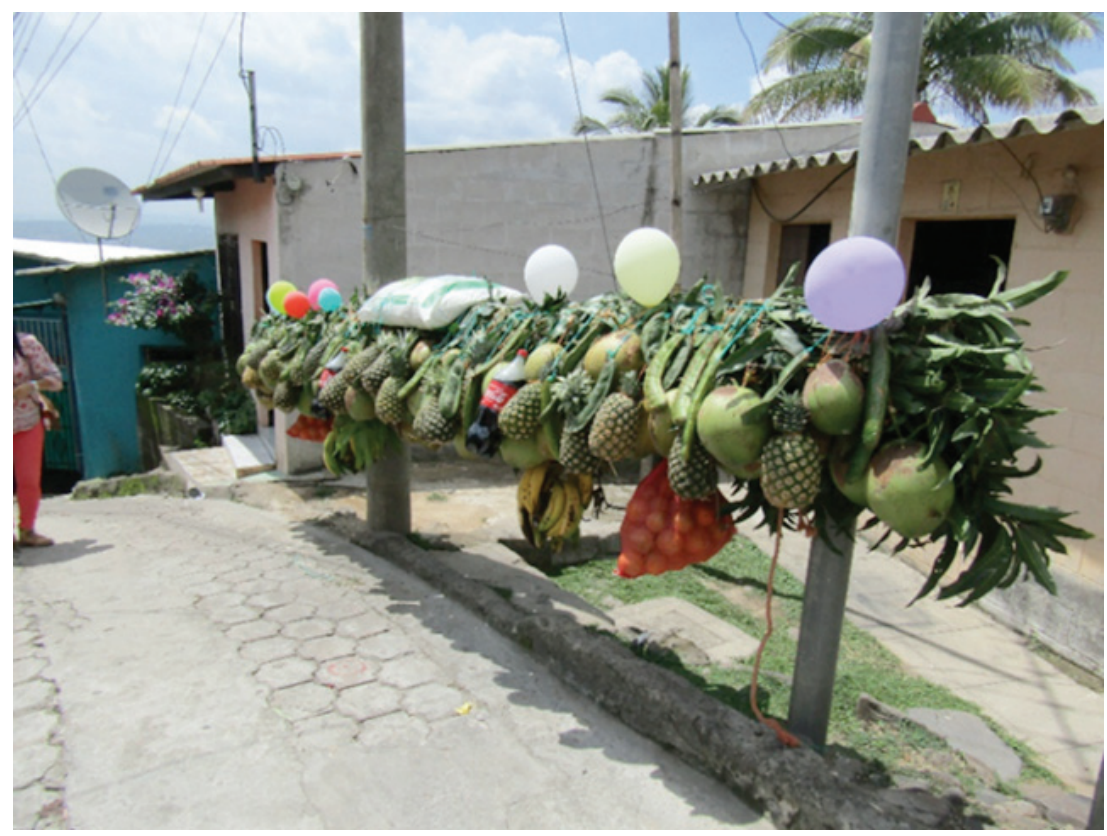

La palanca ostumeña. Fotografía proporcionada por Deisy Candelario de Reyes.

En primer lugar, la fiesta patronal del 23 de enero al 2 de febrero, la Toñita ha logrado traer más gente que la fiesta patronal con la mentada feria, a mi toco ser el nominado de la piña un año, porque gracias a Dios, se me han criado 8 hijos y 19 nietos, 13 bisnietos y todos los que vienen comen aquí, son felices; el patrimonio mío es la piña. Eso lo tienen en las venas, no importa que se queden sin dinero, porque son cuetes, tambores; desde el primero hasta el 31 hacen entradas, aquí le llamamos flores, los 31 días y el 31 es cuando acarrean las palancas, es una tradición fuerte porque allá en el Carrizal es igual, creo que hoy el Carrizal tiene la misma cantidad de habitantes que Ostuma, este año 
los jugadores hicieron una palanca que ni la pudieron levantar en el lomo, la destruyeron para poder llevarla en Pick-up, así es que mire, tenía 1200 cocos y 400 piñas, 3 sacos de abono, a mí me lo contaron. (Guevara Gálvez, 2017)

En el aporte anterior de don Gonzalo Guevara Gálvez, hace referencia a la fiesta patronal del municipio asi como de un elemento identitario en los ostumeños "Las Palancas", las cuales son parte de no solamente de las tradiciones, sino además de su muestra de agradecimiento al Dios, judeo-cristiano, por todo lo recibido en la época de gestación y fertilidad de la Tierra, un elemento ritual presente en las cosmovisiones indígenas, cuando este mismo acto de agradecimiento se lo dedicaban al Xipetotec, el señor de los desollados.

\section{Fotografía 8}

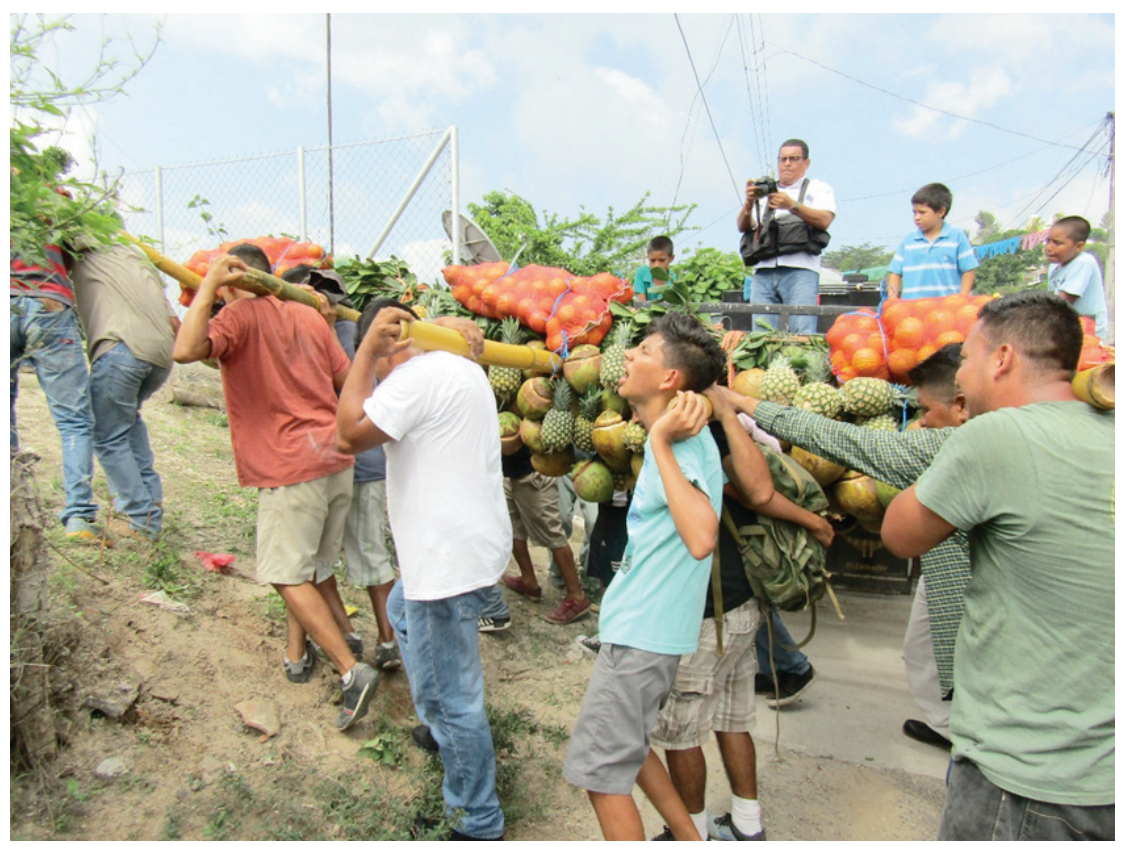

La ritualidad y religiosidad ostumeña, expresado en la palanca ostumeña. Fotografía cortesía de Deisy Candelario de Reyes.

El simbolismo en el proceso ritual de las palancas, también evoca un sentimiento de pertenencia colectiva y de reconocimiento social, en el proceso de elaboración de las palancas, en donde lo material se fusiona con lo inmaterial que representa la espiritualidad de los ostumeños, al celebrar la fertilidad en la producción agrícola, del cambio de época seca a la época lluviosa. 
Asi mismo es importante definir como es el proceso de elaboración de la palanca en Santa María Ostuma; ya que es, en sí mismo el acto ritual, previo a la celebración de la cosecha en el mes de mayo, esto se realiza durante el 31 de dicho mes, participando las diferentes comunidades que integran los 7 cantones, aportando parte de sus cosechas en agradecimiento a Dios y a sus Santos, por las bondades que la tierra fértil de su municipio ha generado. Para dimensionar dicho proceso, en palabra de Ever Díaz (2017), se describe a continuación:

Bueno las palancas están más que todo compuesta de piña, de coco, nosotros le pusimos canastas básicas (este año), licor, gaseosa, le pusimos plátano y abono; eso se entregan el día 31 de mayo [...] el mayordomo se encarga de irlas a recoger a donde las personas que las han agarrado, el año anterior, las fabrican o las hacen [...] pero esto es un trabajo de aproximadamente 4 días, nosotros la comenzamos el día 28 , nos fuimos a la costa a conseguir el coco, a buscar y a comprar la piña por ende es de acá la piña es de acá $[\ldots]$ aproximadamente los organizadores éramos 11 , pero de ahí con las amistades y todo, trabajamos algunos 30 aproximadamente, quiere de bastante gente para poder hacerla, más por el tamaño que hicimos nosotros, que fue de 15 metros de largo tenía 1200 cocos 400 piñas, tenía 4 canastas básicas, dos sacos de abono, licor y gaseosa.

\section{Fotografía 9}

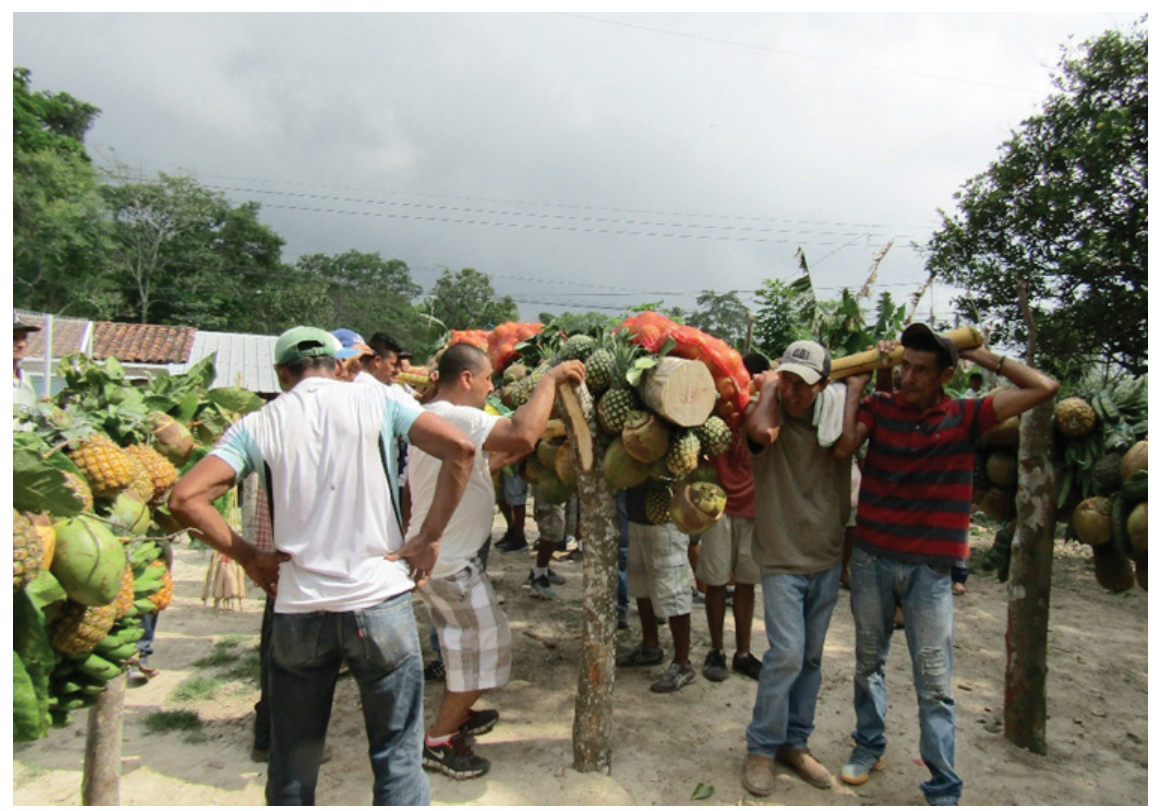

Las palancas en Santa María Ostuma, fotografía proporcionada por Deisy Candelario de Reyes. 


\section{Conclusiones}

- Santa María Ostuma es un crisol de leyendas, tradiciones, costumbres y gastronomía, entre las principales celebraciones se encuentran las fiestas a la santa patrona la Virgen de Candelaria, así como las cofradías, palancas, rezos con sus mayordomías en sus siete cantones, en sus respectivos templos y santos patronos, es tierra de cuevas de duendes, ermitaños y del muluz.; en la gastronomía dan paso a diferentes platos exquisitos en base a piña; pero lo principal, entre sus varios tesoros, es la calidez de su gente, muy amigable que están prestos a servir con gran sentido del respeto y amabilidad, poniendo de manifiesto el orgullo de ser Ostumeño.

- Se puede confirmar que el fruto de la piña genera una dinámica socio cultural en el municipio, expresado en los procesos de producción y comercialización de la piña como tal y sus derivados, generando propuestas y referencias de emprendimiento local, en donde el rol de la mujer se ve exaltado como proveedora responsable del grupo familiar, participando activamente en la religiosisdad y la espiritualidad particularmente en las cofradías; así como , la diversificación y comercializando del producto, por otro lado, en lo culinario, la piña provee de una variedad de presentaciones tales como las pupusas, pan dulce, mermeladas, jaleas, frozen, chicha, vinagres, pizzas, entre otros; todos ellos con la materia prima de la piña. En lo artístico local sobresalen los cobertores de lámparas de exteriores y calles, decoración de iglesia principal, miradores, señalética familiar, obras pictóricas, arte mural y música alegórica a la piña y a la tradición ostumeña, además se impulsan, como actividad turística, dos ferias de la piña al año; una de verano y una de invierno en donde se dan cita más o menos 30,000 visitantes por cada feria.

- Por otro lado, la organización social de los ostumeños responde a sus necesidades tanto religiosas y espirituales, así como de emprendimiento económico y turístico, que se expresan por medio de las tradiciones y las costumbres apoyadas de manera directa e indirectamente de la alcaldía municipal, gracias a su alcaldesa Elsa Antonia Guevara de Melchor, que goza de la confianza de la gente del municipio.

- Por tanto, todo lo anterior da base para que de manera categórica se pueda reconocer al municipio de Santa María Ostuma como la capital de la piña en El Salvador. 


\section{Referentes bibliográficos}

Barfield, T. (2000). Diccionario de Antropología. México D.F., México: Siglo XXI. Beltrán Panameño, S. (29 de junio de 2017). Fruticultor de cultivar Golden. (M. Rodas, Entrevistador)

Campo A., A. (2008). Diccionario Básico de Antropología. Quito, Ecuador: Abya-Yala.

Candelaria Ruano, L. A. (22 de agosto de 2017). Unidad de la mujer, la niñez, adolescencia y adulto mayor. (C. F. Osegueda, Entrevistador)

Candelario de Reyes, D. (29 de junio de 2017). Unidad de proyección social de la Alcaldía Municipal de Santa María Ostuma. (F. E. Santos Alvarenga, Entrevistador)

CONAMYPE. (2015). Un pueblo un producto. Onpaku.

Chito Mejía, F. C. (27 de junio de 2017). Finca Santa Elena, Cantón Carrizal. (C. F. Osegueda, Entrevistador)

Díaz Hernández, A. (1994). Monografía sobre la historia de Santa María Ostuma. Santa María Ostuma.

Diaz Hernández, A. (27 de junio de 2017). El aporte del Coronel desde la monografia de 1994 de Santa María Ostuma. (M. Á. Hernández Vásquez, \& J. M. López Quintana, Entrevistadores)

Diaz, A. (27 de junio de 2017). El aporte del Coronel desde la monografia de 1994 de Santa María Ostuma. (M. Á. Hernández Vásquez, \& J. M. López Quintana, Entrevistadores)

Diaz, E. F. (29 de junio de 2017). Promotor de alfabetización. (M. López, Entrevistador)

Enriz, N. (jul./dic. de 2011). Antropología y juego: Apuntes para la reflexión. Cuadernos de antropología social(34).

Guevara Gálvez, G. (27 de junio de 2017). Productor de piña y cítricos. (F. E. Santos Alvarenga, Entrevistador)

Hernández Sampieri, R., Fernández Collado, C., \& Baptista Lucio, P. (2014). Metodologia de la investigación (Sexta ed.). México, D.F., México: McGraw Hill/Interamericano.

Hope Ponce, M. E., \& Mora Eguiarte, D. (2000). De abominable a zubiburrico. Diccionario de Antropología en la ENAH. Tesis para obtener el titulo de Licenciatura en Etnología y en Antropología Social. México D.F., México: ENAH.

López, N., \& Méndez Candelario, F. (20 dejulio de 2017). Jóvenes emprendedores y fruticultores de la Piña Ostumeña. (M. Á. Hernández Vásquez, \& J. M. López Quintana, Entrevistadores)

López Cañas, E. V., Menjívar Leiva , C. M., \& Meza Martínez, C. G. (7 de abril de 2015). "EL MARCO EPISTEMOLÓGICO DEL ENFOQUE DE GÉNERO MANIFIESTO EN EL CURRÍCULO DE FORMACIÓN FAVORECE LAS PRÁCTICAS PEDAGÓGICAS SEXISTAS DE LOS 
Y LAS. Tesis para obtener el grado de licenciatura en ciencias de la educación. San Salvador, El Salvador: Editorial Universitaria.

Miller, B. (2016). Antropología cultural (Septima ed.). Madrid, España: Pearson Educación.

Montes, S. (1977). Etnohistoria de El Salvador, Cofradias, hermandades y Guachivales. San Salvador: direccion de publicaciones del ministerio de edcacion.

Naciones Unidas. (miercoles 21 de octubre de 2015). Transformar nuestro mundo: la Agenda 2030 para el desarrollo sostenible. Nueva York: Asamblea General de las Naciones Unidas.

Navarro Ardoy, L., Pasadas del Amo,, S., \& Ruiz Ruiz, J. (2014). LA TRIANGULACIÓN METODOLÓGICA EN EL ÁMBITO DE LA INVESTIGACIÓN SOCIAL;. DIGITAL.CSIC, 10.

Pérez de Aguillón, M., \& Aguillón López, J. Á. (18 de julio de 2017). La Religiosidad Popular Ostumeña. (J. M. López Quintana, \& M. Á. Hernández Vásquez, Entrevistadores)

Pérez de Tudela, J. B. (2012). Investigación cualitativa (Segunda ed.). México D.F., México: Alfaomega.

PNUD. (julio de 2014). EMPRENDEDURISMO . San Salvador, El Salvador. R. Ayllón, J. (2013). Antropología paso a paso. Madrid: Palabra.

Reyes, D. C. (29 de Junio de 2017). Unidad de proyección social de la Alcaldía Municipal de Santa María Ostuma . (F. Santos, Entrevistador)

Sandoval, I. A., \& Torres, E. E. (2011). Guia Técnica del cultivo de la Piña. San Salvador: CENTA-MAG.

Tejada viuda de Anaya, E. (22 de agosto de 2017). Artesana de las candelas ostumeñas. (F. E. Santos Alvarenga, Entrevistador)

Vazques, C. (19 de Marzo de 2016). Historia de vida. (F. Santos, Entrevistador) 


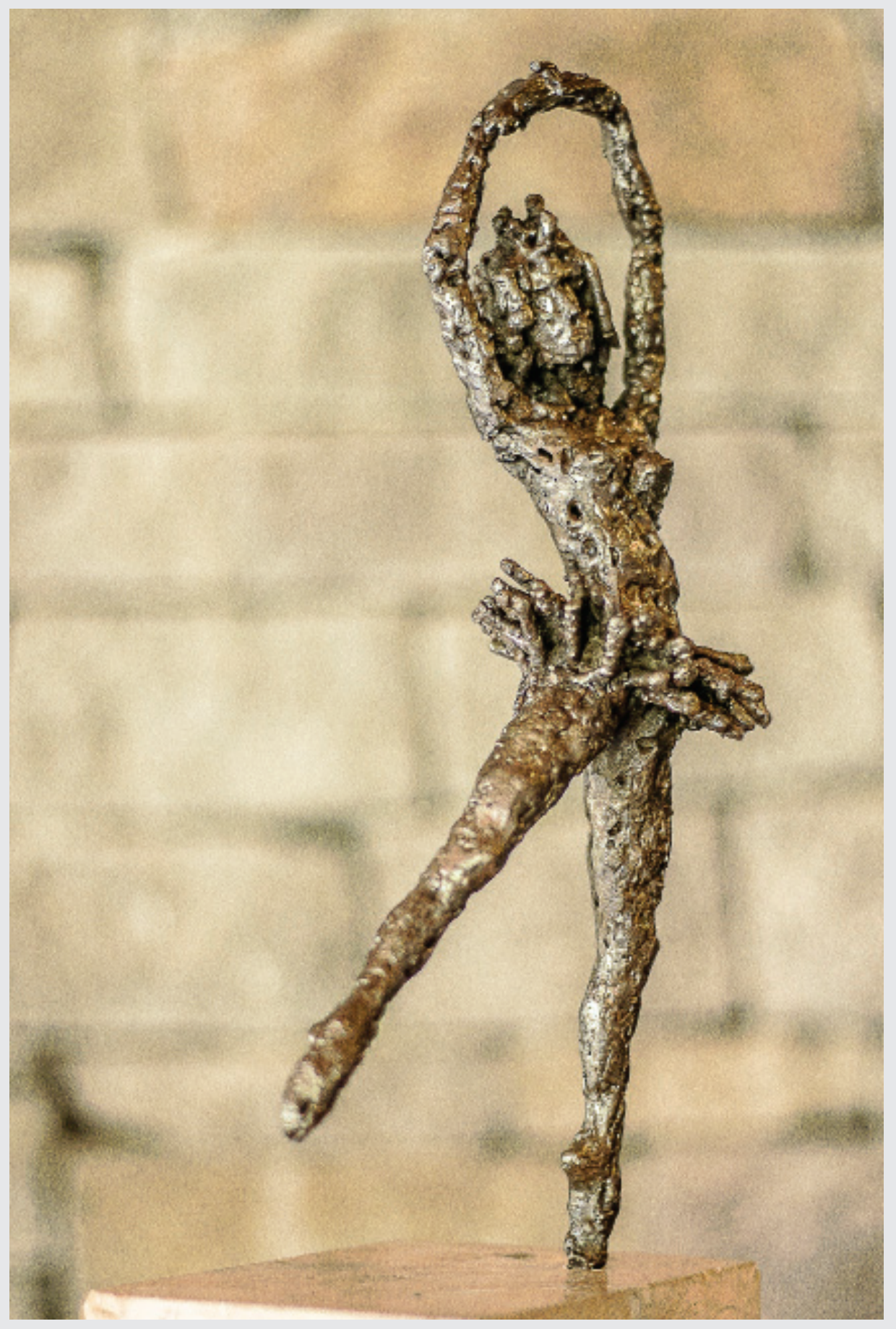

Rubén Martínez Bulnes 